\title{
PERBANDINGAN EKSPERIMENTAL DAN SIMULASI FREKUENSI PRIBADI PADA STRUKTUR SPIN- DEL CNC
}

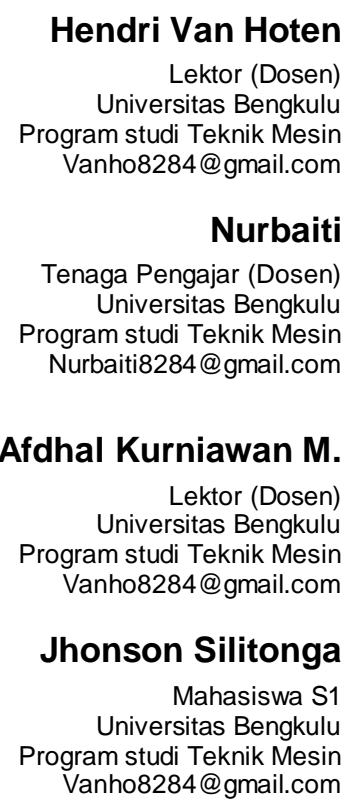

The Research was about the comparison between experiment and simulation of natural frequency in $C N C$ spindle. CNC spindle vibration will reduce machine tool performance. It could lead to the damage of the machine tool. The spindle structure unbalances of machine tools will cause vibration when it is operated. In the CNC machine, the spindle shaft vibration should be minimum. Based on this point, the natural frequency testing on the spindle shaft structure was carried out. The experiments were conducted by employing oscilloscope which could provide the vibration data in the time domain. The data was converted into the frequency domain using FFT. Measurements were carried out on 7 times of testing. Every one time of testing, 10 data were taken at each testing points. The tests were conducted at 10 testing points. Therefore, the total data obtained were 700 test data. The test results were then compared with the results of simulation modeling in 10 vibrate modes using Solidwork software. After testing and simulations were compared, 4 personal frequency values were obtained in the test that uses a measuring instrument and 6 personal frequency values could not be read. These were because the accelerometer used could not read up to $0 \mathrm{~Hz}$ frequency. Natural frequency obtained from simulations and tests were expressed in the percentage of errors. The largest error value in the 9 th vibration mode measurement with a natural frequency was $2117.96 \mathrm{~Hz}$ with an error of $0.32 \%$. The smallest error value was $0.11 \%$ with a natural frequency of $2995.79 \mathrm{~Hz}$.

Keywords: Vibration, FFT, Oscilloscope, Error Value.

\section{PENDAHULUAN}

Perkembangan teknologi dan kemajuan zaman meningkatkan pertumbuhan industri manufaktur. Berdasarkan info dari liputan6.com pada tanggal 3 Februari 2020, data dari Badan Pusat Statistik (BPS) pertumbuhan industri manufaktur besar dan sedang pada tahun 2019 naik sebesar 4,01 persen dari tahun sebelumnya. Hal ini tentu akan mendorong kemajuan teknologi manufaktur dan banyak inovasi yang diciptakan. Peningkatan produktivitas dan kualitas dari produk yang dihasilkan merupakan tantangan bagi industri pemesinan masa kini [1]. Proses manufaktur mesin perkakas memegang peran yang sangat penting terhadap kualitas produk yang akandihasilkannya. Pada mesin perkakas dihasilkan efek getaran selama proses pemotongan berlangsung, diantaranya disebabkan oleh gaya pemotongan dan getaran akibat eksitasi pribadi (frekuensi pribadi) [2].

Getaran adalah gerakan bolak-balik yang terjadi pada posisi seimbangnya, getaran terdiri dari frekuensi dan periode [2]. Frekuensi adalah banyaknya jumlah getaran yang terjadi dalam satu detik. Satuan frekuensi dalam sistem internasional adalah Hertz $(\mathrm{Hz})$ dan periode adalah waktu yang diperlukan untuk melakukan satu kali getaran satuan priode dalam sistem internasional adalah sekon (s). Analisis getaran sangat penting untuk merancang sistem dinamika yang optimal agar dapat beroperasi secara aman dan andal $[3,4]$. Analisis getaran bebas pada pada salah satu bagian mesin merupakan bagian penting dalam analisis keseluruhan sistemnya [4].

Pada setiap komponen kontruksi alat tertentu memiliki frekuensi pribadi (frekuensi kesukaannya). Begitu juga pada spindle yang berfungsi sebagai pemutar benda kerja pada mesin perkakas CNC. CNC merupakan mesin canggih yang digerakkan menggunakan program [5]. Spindle mesin bubut CNC 
merupakan bagian yang sangat penting dalam menghasilkan produk yang berkualitas dan bermutu. Pada penelitian ini yang diamati adalah frekuensi pribadi yang terjadi pada spindle bubut CNC dengan membandingkan hasil simulasi menggunakan solidwork dan eksperimental dengan accelerometer dan osilloscope yakogawa DL-750P dengan memberi beban impack menggunakan impack hammer. Penelitian ini akan dilakukan analisis eksperimental frekuensi pribadi dan modus getar untuk benda dalam keadaan bebas [6].

Benda yang memiliki massa dan sifat elastisitas akan bergetar. Kondisi dimana saat benda itu bergerak secara bolak-balik atau periodik terhadap posisi setimbangnya (referensinya) atau posisi titik benda tersebut berada dalam keadaan diam dikatakan dengan bergetar. Gambar 1 menampilkan getaran pada sistem pegas sederhana.

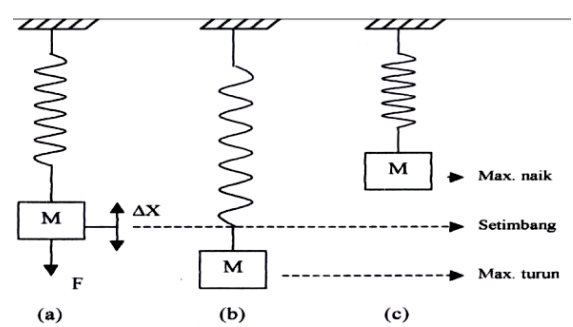

Gambar 1: Getaran pada sistem pegas sederhana [7].

Benda yang mempunyai massa (M) berada dalam kondisi diam (a). Kemudian dikenakan gaya senilai $\mathrm{F}$, maka perpindahan posisi maksimum $(\Delta \mathrm{x})$ benda bergantung besarnya nilai $\mathrm{F}(\mathrm{b})$. Massa dan kekuatan tarik pegas melawan arah gaya tersebut. Jika gaya sebesar F tidak diberikan lagi pada benda (M) maka akibat kekakuan pegas benda tersebut akan tertarik kembali ke atas karena energi postensial yang tersimpan pada pegas (c). Perpindahan maksimum $(\Delta \mathrm{x})$ keatas tergantung dari kekuatan tarik dari energi potensial pegas akibat kekakuannya serta dari massa benda itu sendiri. Proses tersebut akan berulang hingga hilangnya pengaruh dari gaya luar $\mathrm{F}$ tersebutdan benda akan kembali pada posisi setimbang (diam). Pergerakan massa naik turun hingga setimbang inilah yang disebut osilasi mekanik.

Getaran yang terjadi pada sebuah sistem pegas-massa, karakteristiknya dapat dipelajari dengan membandingkan (memplotkan) gerakan massa terhadap waktu, fenomena ini ditampilkan pada Gambar 2.

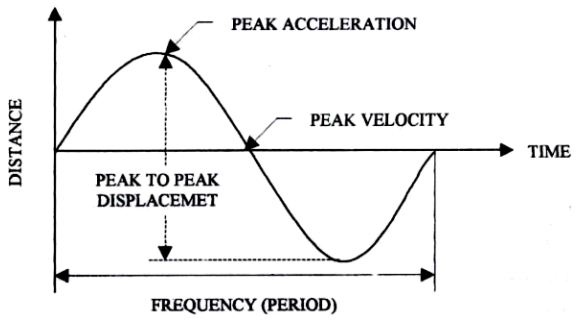

Gambar 2: Fenomena getaran pada gerakan massa terhadap waktu (time) [7].

Satu siklus gerakan sebuah massa adalah gerak dari massa pada posisi seimbangnya (netral) ke batas maksimum pergerakannya, setelah itu bergerak kembali ke posisi setimbang kemudian bergerak ke bagian bawah serta kembali lagi ke posisi netralnya. Satu siklus pergerakan massa ini dinamakan periode. Frekuensi merupakan banyaknya siklus gerakan massa yang terjadi pada waktu tertentu. Ketika dilakukan pengukuran nilai frekuensi getaran massa didapatkan nilai amplitudo. Dimana amplitudo merupakan seberapa jauh penyimpangan terjadi yang dibandingkan terhadap titik netral awal pada tiap-tiap nilai frekuensi yang akan diukur. Ketika dilakukan pengukuran getaran, besaran dari amplitudo dapat ditentukan dalam berbagai besaran tergantung parameter apa yang akan digunakan.. Parameter gelombang sinusoidal diantaranya percepatan, kecepatan dan perpindahan, selengkapnya dapat dilihat pada Tabel 1 dibawah ini.

Tabel 1: Parameter amplitudo.

\begin{tabular}{c|l}
\hline PARAMETER AMPLITUDO & SATUAN \\
\hline Displacement & $(\mathrm{m}, \mathrm{mm}, \mu \mathrm{m})$ \\
\hline Velocity & $(\mathrm{m} / \mathrm{s}, \mathrm{mm} / \mathrm{s}, \mu \mathrm{m} / \mathrm{s})$ \\
\hline Acceleration & $\left(\mathrm{m} / \mathrm{s}^{2}\right)\left(\mathrm{g}=9,81 \mathrm{~m} / \mathrm{s}^{2}\right)$ \\
\hline
\end{tabular}


Berdasarkan parameter utama yang digunakan terdapat juga bentuk ekspresi lain dari amplitudo pada gelombang sinus. Pertama, peak to peak adalah nilai yang mengindikasikan jarak perpindahan antar puncak maksimum dari gelombang. Ini sangat bermanfaat contohnya untuk getaran dari bagian mesin yang kritis untuk tegangan maksimum atau akibat kelonggaran mekanik. Kedua, peak adalah nilai yang mengindikasikan perpindahan maksimum dari satu puncak. Tidak ada nilai yang mengacu pada rentetan waktu gelombang yang telah terjadi. Ketiga, average ini dianggap sebagai titik yang dibatasi karena tak memiliki hubungan yang berguna terhadap nilai fisik. Keempat, RMS (Root Mean Square) dalam kelistrikan, dianggap sebagai nilai arus efektif. Namun juga dianggap sebagai nilai amplitudo paling relevan karena mengacu pada sejarah terjadinya gelombang yang secara langsung berhubungan dengan besarnya kandungan energi, yang mana akan bersifat menghancurkan dari suatu getaran. Kelima, frekuensi adalah jumlah siklus dalam tiap satu satuan waktu. Besarnya dapat dinyatakan dalam siklus per detik (cycle per second) atau siklus per menit (cycle per minute) atau waktu yang dibutuhkan untuk menyelesaikan satu siklus gerakan selama periode 1detik atau 1 menit disebut dengan frekuensi, yang diukur dengan satuan Hertz (Hz). Rumus dari frekuensi getaran dapat dilihat pada persamaan 1.

$$
f=n / t
$$

dengan:

$$
\begin{aligned}
f & =\text { Frekuensi }(\mathrm{Hz}) \\
\mathrm{n} & =\text { Jumlah getaran } \\
\mathrm{t} & =\text { Waktu (sekon) }
\end{aligned}
$$

atau

$$
f=\frac{1}{T}
$$

dengan,

$\mathrm{T}=$ periode getaran (sekon)

Frekuensi getaran penting untuk diketahui ketika menganalisa getaran mesin untuk menunjukan masalah apa yang terjadi pada mesin tersebut. Frekuensi getaran yang diketahui akan dapat mengindentifikasi bagian mesin yang mengalami kerusakan (fault) dan juga penyebabnya. Keenam, frekuensi pribadi adalah frekuensi dari sistem getaran bebas (free vibration) atau frekuensi "kesukaan" dari sesuatu benda untuk bergetar yang hanya dipengaruhi oleh massa dan kekakuan [8]. Nilainya beragam tergantung sifat dan bentuk dari setiap benda. Frekuensi pribadi merupakan salah satu parameter dari dinamika $[9,10]$. Bergetarnya suatu benda pada nilai frekuensi kesukaanya atau frekuensi pribadinya dinamakan resonansi. Besarnya frekuensi pribadi tergantung pada massa dan kekakuan. Mesin atau struktur tertentu adalah sistem banyak derajat kebebasan (multi degree of freedom) sehingga jumlah frekuensi pribadinya banyak. Untuk mesin atau struktur dengan bentuk yang kompleks, misal rotor turbin memiliki banyak (tak hingga) frekuensi pribadi. Namun yang penting untuk diketahui adalah frekuensi pribadi yang berada direntang putaran operasi mesin atau dinamakan juga putaran kritis [11]. Jika sebuah benda berputar pada putaran kritisnya, maka akan terjadi resonansi atau dengan kata lain resonansi dapat terjadi jika frekuensi putaran sama dengan salah satu frekuensi pribadi benda tersebut [12]. Resonansi akan meningkatkan getaran mesin [13]. Getaran yang berlebih pada mesin bisa menyebabkan kerusakan dan efek yang merugikan pada struktur pondasi sebagai penopang [14]. Kekakuan adalah sifat dari material. Pegas memiliki konstanta pegas (k), Sedangkan material memiliki modulus elastisitas (modulus young) yang merupakan perbandingan tegangan dan regangan. Modulus Young dapat ditentukan dengan menggunakan simulasi elemen hingga berdasarkan ukuran geometri benda [15]. Rumus frekuensi pribadi dapat dilihat pada persamaan 3.

$$
f n=\frac{1}{2 \pi} \cdot \sqrt{\frac{k}{m}}
$$

dengan:

$$
\begin{aligned}
f n & =\text { Frekuensi Pribadi }(\mathrm{Hz}) \\
\mathrm{k} & =\operatorname{Kekakuan}(\mathrm{N} / \mathrm{m}) \\
\mathrm{m} & =\text { Massa }(\mathrm{kg})
\end{aligned}
$$




\section{METODE DAN BAHAN}

Metode pada penelitian ini yaitu membandingkan nilai frekuensi pribadi material spindle mesin CNC antara pemodelan menggunakan software solidwork dengan hasil eksperimental.

\subsection{Pemodelan Solidwork.}

Pada penelitian ini pemodelan menggunakan software solidwork dengan model 3D. Setelah selesai pemodelan, selanjutnya input properties material spindle yang akan diuji dapat dilihat pada tabel 2 .

Tabel 2: komposisi material AISI 4340.

\begin{tabular}{l|l|l}
\hline PROPERTY & VALUE & UNIT \\
\hline Elastic Modulus & 205000 & $\mathrm{~N} / \mathrm{mm}^{2}$ \\
\hline Poisson's Ratio & 0.285 & - \\
\hline Shear Modulus & 80000 & $\mathrm{~N} / \mathrm{mm}^{2}$ \\
\hline Mass Density & 7850 & $\mathrm{~kg} / \mathrm{m}^{3}$ \\
\hline Tensile Strength & 745 & $\mathrm{~N} / \mathrm{mm}^{2}$ \\
\hline Yield Strength & 470 & $\mathrm{~N} / \mathrm{mm}^{2}$ \\
\hline Thermal Expansion Coefficient & $1.23 \mathrm{e}-005$ & $/ \mathrm{K}$ \\
\hline Thermal Conductivity & 44.5 & $\mathrm{~W} /(\mathrm{m} . \mathrm{K})$ \\
\hline Specific Heat & 475 & $\mathrm{~J} /(\mathrm{kg} . \mathrm{K})$ \\
\hline & &
\end{tabular}

Setelah material diinputkan maka langkah selanjutnya proses meshing atau model dibagi menjadi elemen-elemen sekecil mungkin sebanyak 98798 mode.

Setelah pemodelan dan meshing dilakukan sesuai ukuran spindle maka lanjut ke proses simulasi untuk mendapatkan frekuensi pribadi dan modus getar pada struktur tersebut. Hasil pemodelan akan dibandingkan dengan hasil eksperimental.

\subsection{Alat dan Bahan untuk Eksperimen}

Alat dan bahan sebagai perangkat yang menunjang pengambilan data sebagai berikut:

\section{Osciloschope}

Osiloskop/Scope Corder adalah alat ukur elektronik yang dapat memetakan atau memproyeksikan sinyal listrik dan frekuensi menjadi gambar grafik agar dapat dibaca dan mudah dipelajari. Dengan menggunakan Osiloskop, bentuk gelombang dari sinyal listrik atau frekuensi dalam suatu rangkaian elektronika dapat diamati dan kemudian dilakukan analisa. Pada umumnya data akan ditampilkan dalam bentuk grafik 2D sumbu $\mathrm{X}$ dan $\mathrm{Y}$. Umumnya nilai $\mathrm{Y}$ adalah amplitudo dan $\mathrm{X}$ adalah frekuensi atau waktu tergantung domain yang digunakan. Dalam percobaan ini osiloskop yang digunakan adalah YOKOGAWA DL 750P ScopeCorder, seperti terlihat pada Gambar 3.

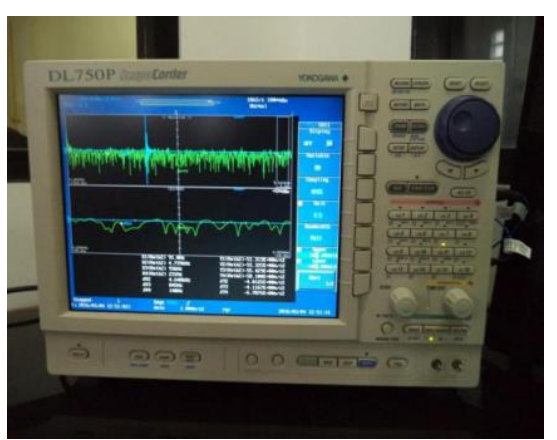

Gambar 3: Yokogawa DL 750P ScopeCorder.

\section{Piezoelectric Accelerometer}

Alat ini merupakan sensor getaran yang digunakan untuk mendeteksi getaran yang terjadi di suatu bidang solid dimana ia ditempatkan. Tampilan akselerometer yang digunakan bisa dilihat pada Gambar 4 . 
Gambar 4: Piezoelectric Accelerometer.

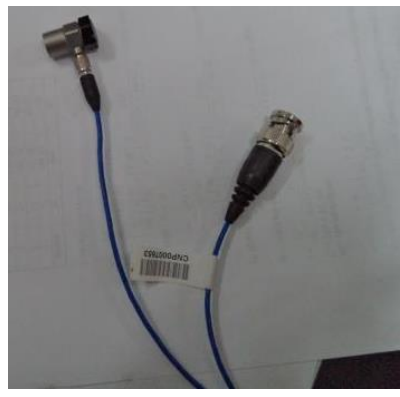

\section{Impact Hammer}

Alat ini digunakan untuk menginput gaya ke spesimen uji sehingga menimbulkan efek getaran. Tampilan dari Impact hammer yang dipergunakan bisa dilihat pada Gambar 5.

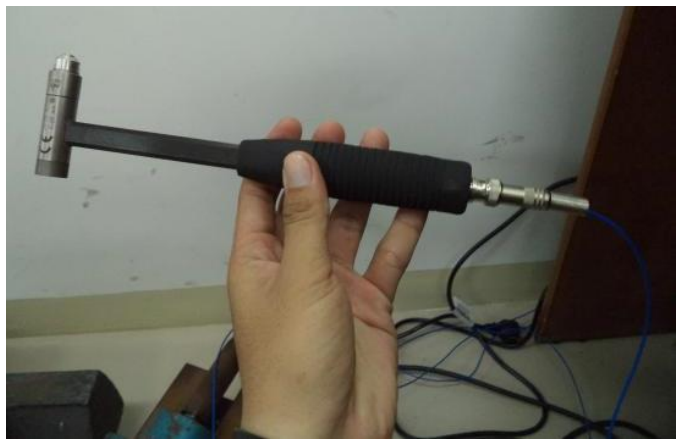

Gambar 5: Impact Hammer.

Ban dalam

Ban dalam digunakan untuk mengurangin efek redaman yang terjadi pada saat pengujian dilakukan. Ban dalam yang digunakan pada apenelitian ini dapat dilihat pada Gambar 6.

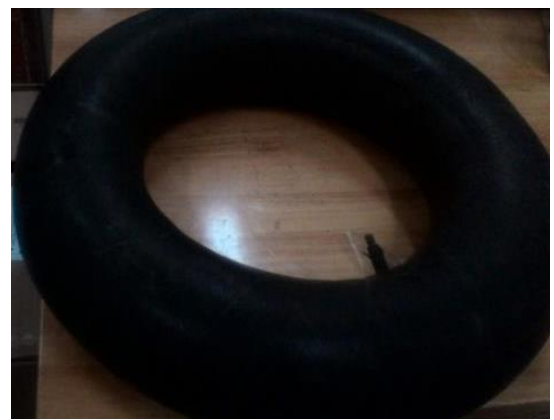

Gambar 6: Ban dalam.

Spindle bubut CNC AISI 4340

Spindle bubut $C N C$ digunakan pada pengujian yang akan di cari frekuensi pribadinya dengan bahan AISI 4340. Gambar dari spindle dapat dilihat pada Gambar 7.

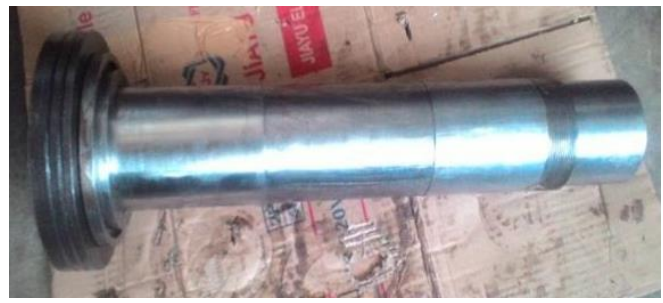

Gambar 7: Spindle Bubut CNC. 


\subsection{Langkah Pengambilan Data}

Dalam melakukan suatu pengujian perlu diperhatikan kesiapan alat-alat yang akan digunakan serta jenis pengujian yang akan dilakukan. Persiapkan alat-alat yang akan digunakan serta pembagian titik sampel pengujian yang akan dilaksanakan dan menampilkan data yang diinginkan. Setting alat pengujian struktur spindle bubut CNC dapat dilihat pada Gambar 8.

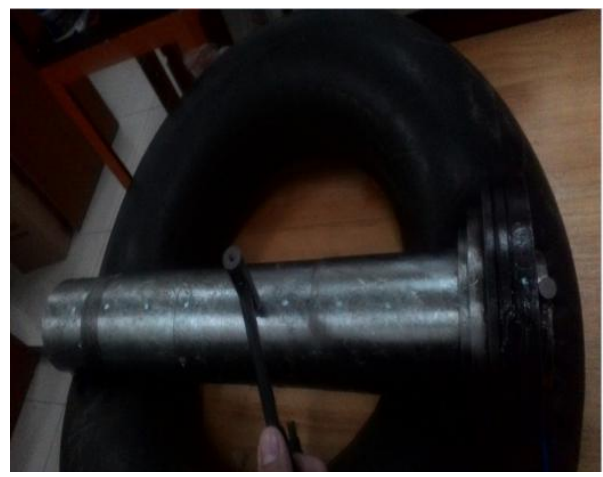

Gambar 8: Tampak atas setting alat Pengujian.

Langkah pengujian penelitian ini sebagai berikut set up spindle yang akan di uji, lakukan pembagian titik pengujian sepanjang spindle sebanyak 10 titik, setting osiloskop yang digunakan, tempatkan accelerometer pada titik pengujian yang telah ditentukan dan lakukan pemukulan pada bagian tengah spindle. Skema penelitian dapat dilihat pada Gambar 9.

Keterangan Gambar :

A.Titik Peletakan accelerometer

B.Titik Pemukulan impack hammer

C.Impack Hammer

D.Accelerometer

E.Ossiloscope yakogawa DL-750P

F. modul 701250(Ch1)

G. modul 701275(Ch11)

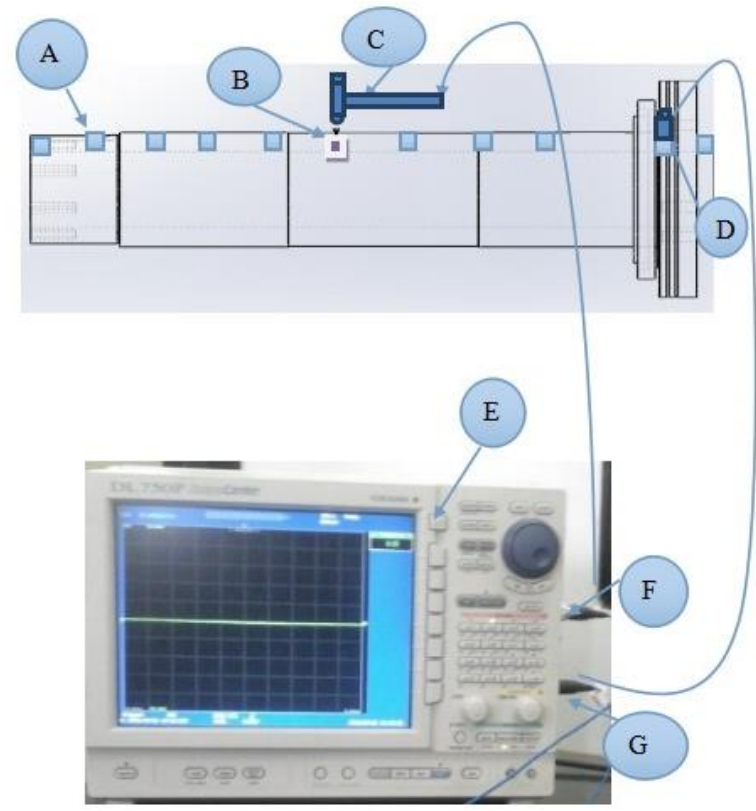

Gambar 9: Tampak samping skema pengujian.

\section{HASIL DAN DISKUSI}

Hasil pengujian yang dilakukan terhadap spindle CNC menggunakan osiloskop yakogawa dapat dilihat pada Gambar 10 dan 11. Gambar 10 merupakan hasil pengujian berupa gelombang domain waktu, sedangkan Gambar 11 gelombang domain frekuensi. 


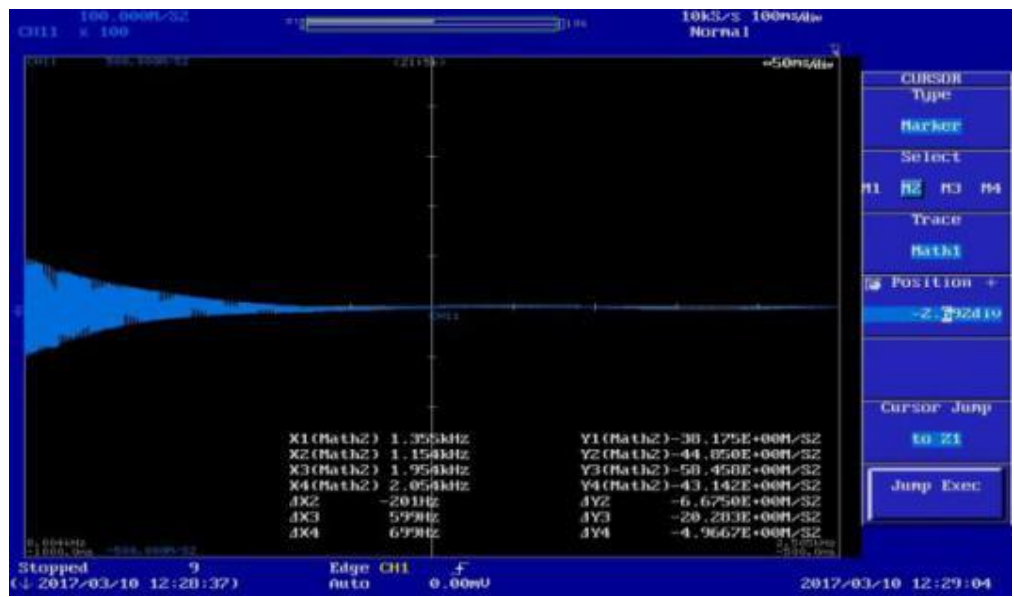

Gambar 10: Hasil pengujian berupa gelombang domain waktu.

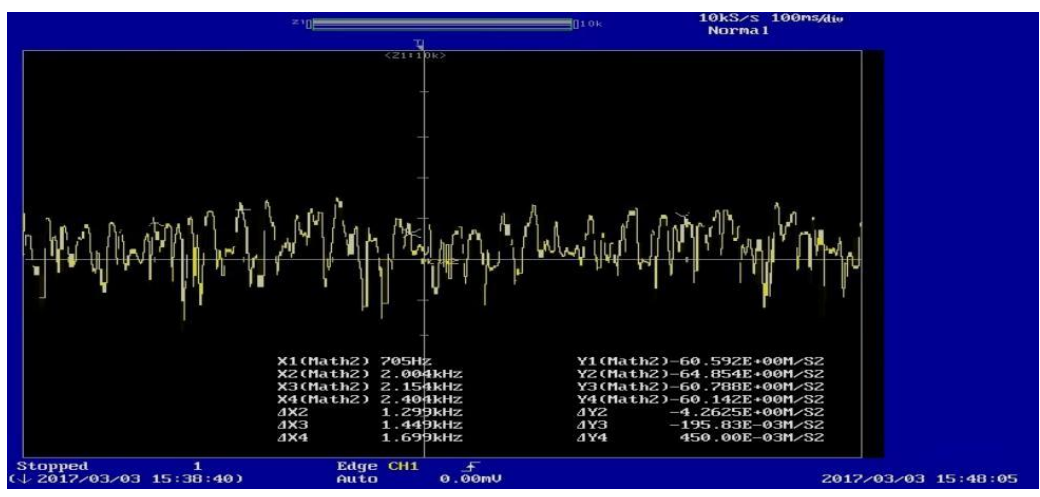

Gambar 11: Hasil pengujian berupa gelombang domain frekuensi.

\subsection{Hasil Data Perbandingan}

Dari pengamatan yang dilakukan maka didapatkan hasil dari perbandingan data. Data yang dapat dilihat dengan menggunakan simulasi dan eksperimen dibandingkan untuk mengetahui besar error yang terjadi. Nilai frekuensi pribadi yang akan diambil sebanyak 10 data simulasi dan 10 modus getar frekuensi pribadinya. Hasil dari simulasi modus getar yang pertama pada solidwork adalah dengan frekuensi pribadi 0 $\mathrm{Hz}$ dapat dilihat pada Gambar 12. Nilai yang terbaca pada alat ukur pada modus getar ke-1 dengan frekuensi $0 \mathrm{~Hz}$ adalah tidak ada nilai yang terbaca. Hasil dari simulasi modus getar yang ke-2 pada solidwork adalah dengan frekuensi pribadi $0 \mathrm{~Hz}$ dapat dilihat pada Gambar 13. Nilai yang terbaca pada alat ukur pada modus getar ke-2 dengan frekuensi $0 \mathrm{~Hz}$ juga tidak ada nilai yang terbaca. Hasil dari simulasi modus getar yang ke-3 pada solidwork adalah dengan frekuensi pribadi $0.0000000023716 \mathrm{~Hz}$ dapat dilihat pada Gambar 14. Nilai yang terbaca pada alat ukur pada modus getar ke-3 adalah tidak ada nilai yang terbaca. Hasil dari simulasi modus getar yang ke-4 pada solidwork adalah dengan frekuensi pribadi $0.00019727 \mathrm{~Hz}$ dapat dilihat pada Gambar 15. Nilai yang terbaca pada alat ukur pada modus getar ke-4 adalah tidak ada nilai yang terbaca. Hasil dari simulasi modus getar yang ke-5 pada solidwork adalah dengan frekuensi pribadi $0.00019771 \mathrm{~Hz}$ dapat dilihat pada Gambar 16. Nilai yang terbaca pada alat ukur pada modus getar ke-5 adalah tidak ada nilai yang terbaca. Hasil dari simulasi modus getar yang ke-6 pada solidwork adalah dengan frekuensi pribadi $0.00019771 \mathrm{~Hz}$ dapat dilihat pada Gambar 17. Nilai yang terbaca pada alat ukur pada modus getar ke-6 adalah tidak ada nilai yang terbaca. Hasil dari simulasi modus getar yang ke-7 pada solidwork adalah dengan frekuensi pribadi $1315.6 \mathrm{~Hz}$ yang dapat dilihat dari Gambar 18. Nilai yang dapat terbaca pada alat ukur pada modus yang ke-7 dapat dilihat pada tabel 3. Hasil dari simulasi modus getar yang ke-8 pada solidwork adalah dengan frekuensi pribadi $1316 \mathrm{~Hz}$ yang dilakukan dapat dilihat dari Gambar 19. Nilai yang dapat terbaca pada alat ukur pada modus yang ke-8 dapat dilihat pada tabel 4. Hasil dari simulasi modus getar yang ke-9 pada solidwork adalah dengan frekuensi pribadi $2111.1 \mathrm{~Hz}$ yang dilakukan dapat dilihat dari Gambar 20. Nilai yang dapat terbaca pada alat ukur pada modus yang ke-9 dapat dilihat pada Tabel 5. Nilai yang dapat terbaca pada alat ukur pada modus yang ke-10 dapat dilihat pada tabel 6. Hasil dari simulasi modus getar yang ke-10 pada solidwork adalah dengan frekuensi pribadi $2992.2 \mathrm{~Hz}$ yang dilakukan dapat dilihat dari Gambar 21. 

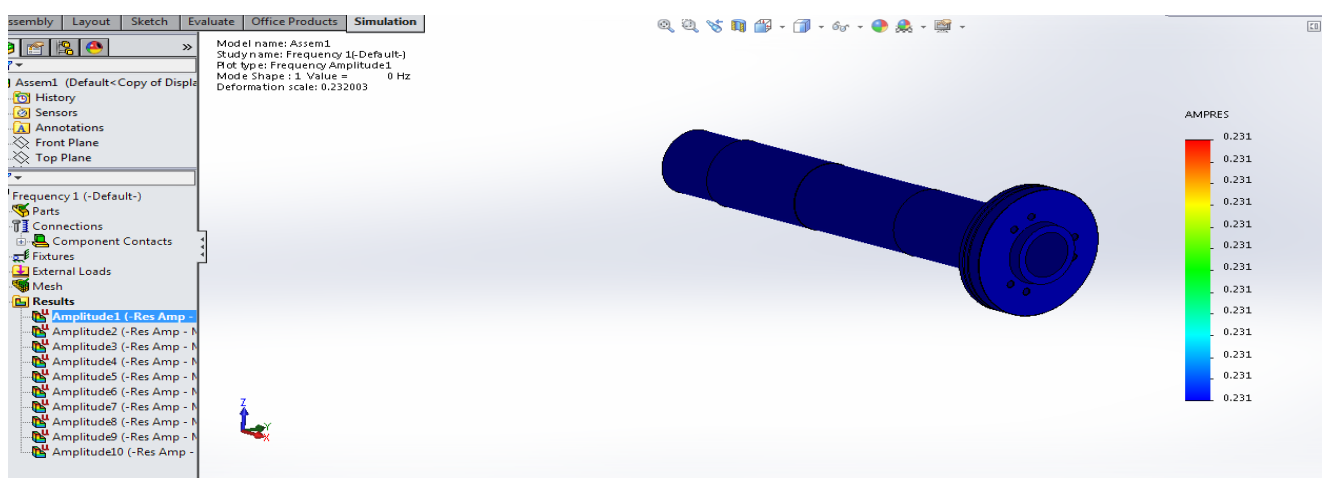

Gambar 12: Modus Getar ke-1 Pada Solidwork.
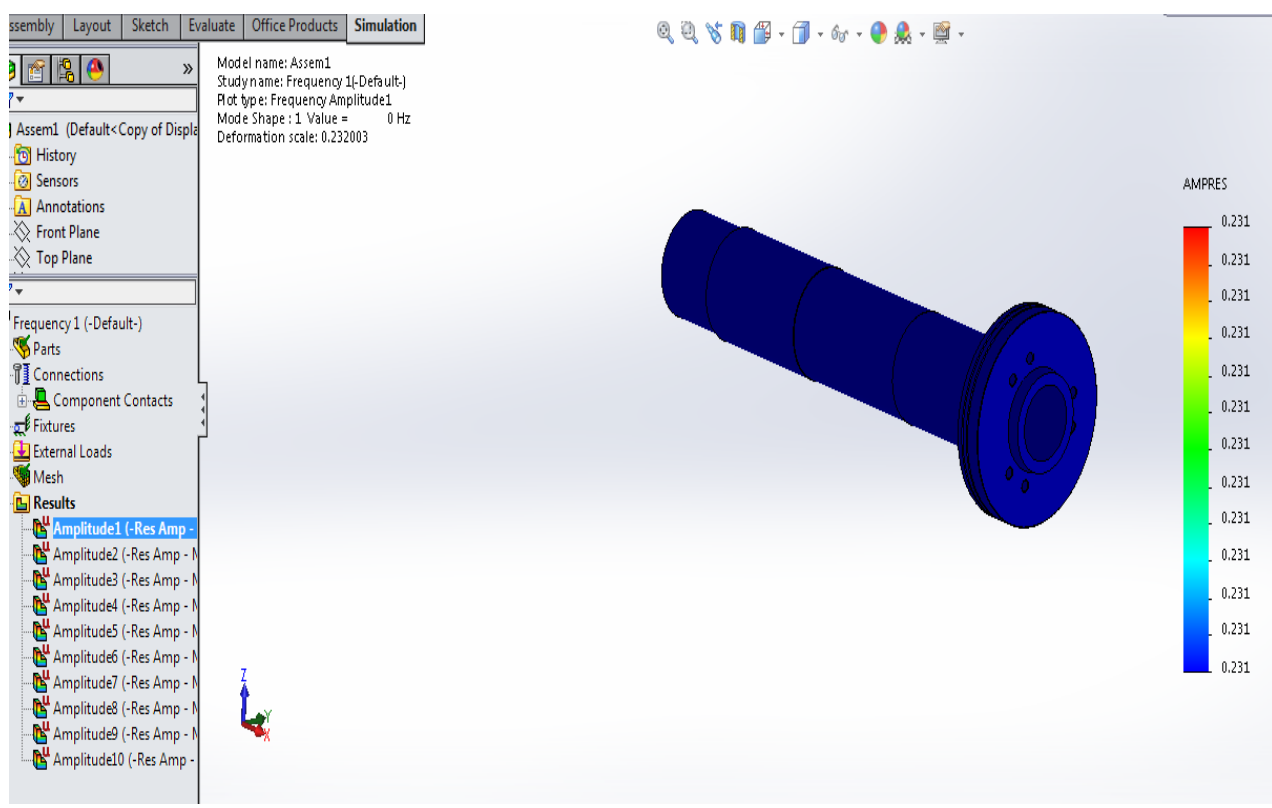

Gambar 13: Modus Getar ke-2 Pada Solidwork.

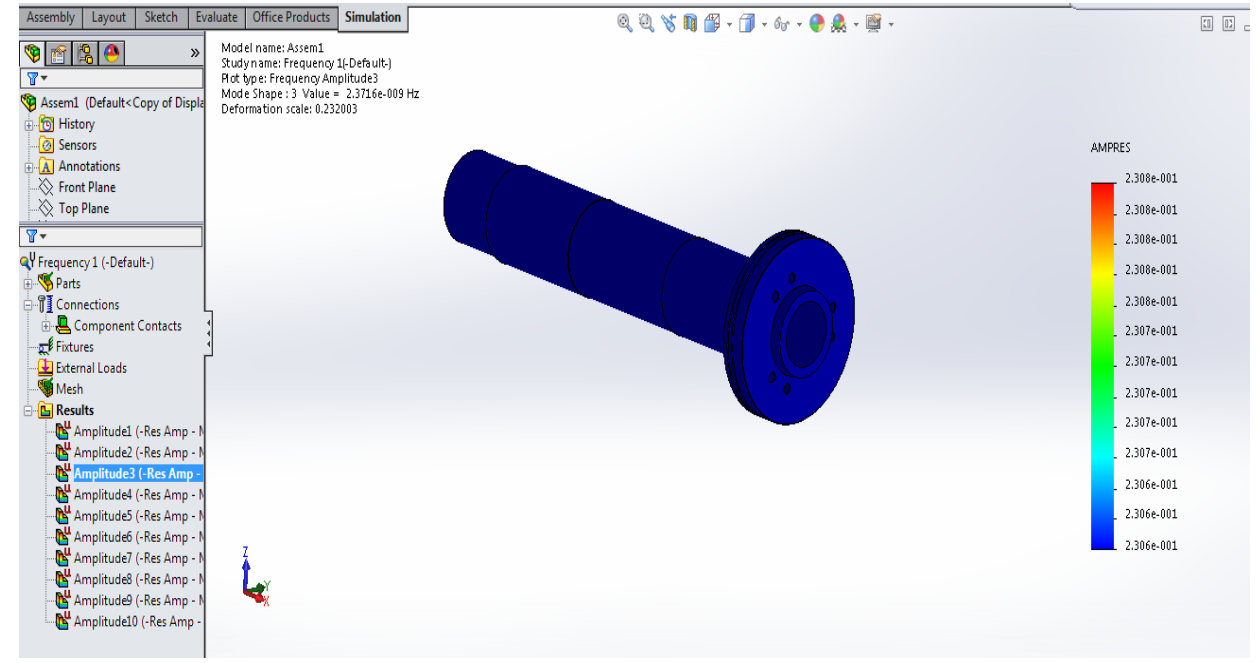

Gambar 14: Modus Getar ke-3 Pada Solidwork. 


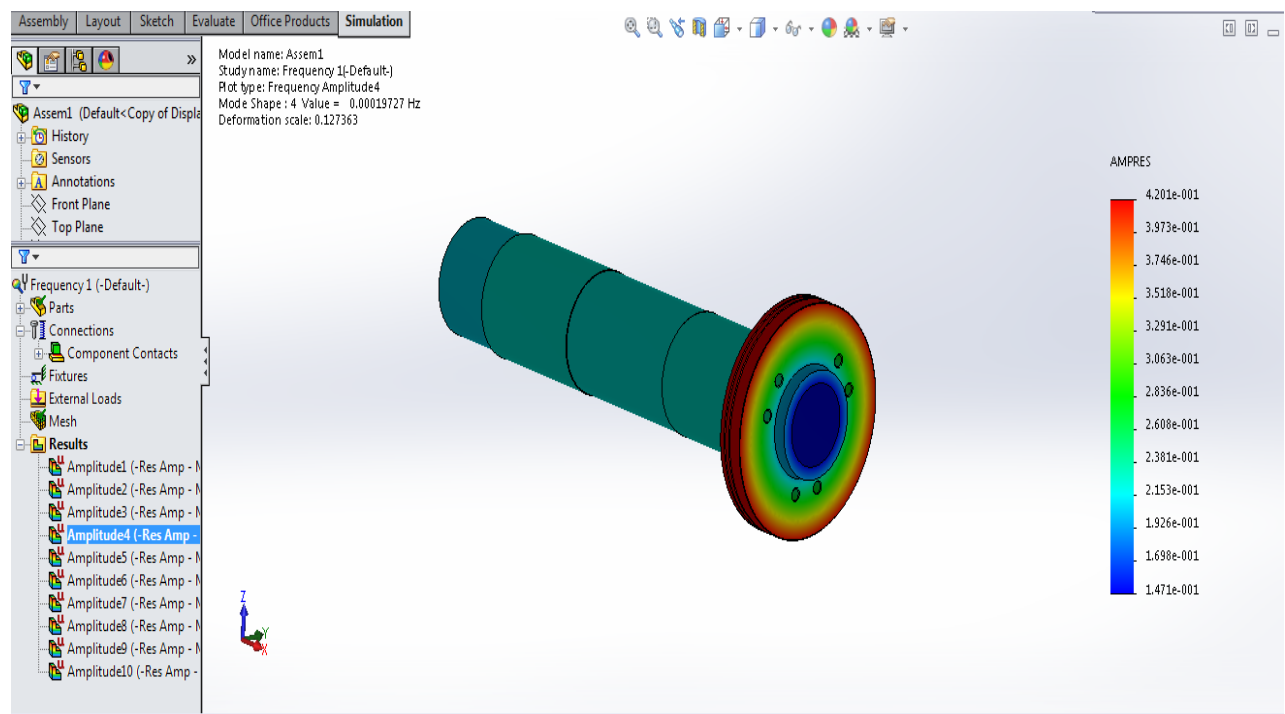

Gambar 15: Modus Getar ke-4 Pada Solidwork.

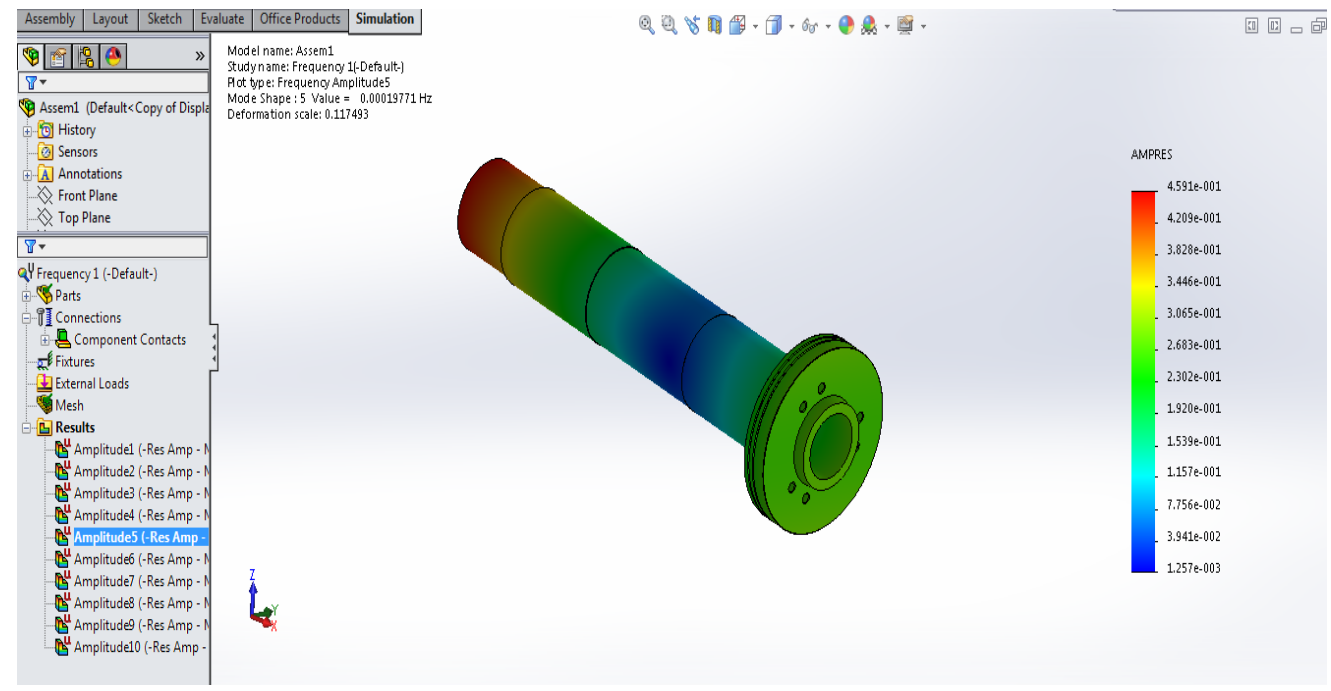

Gambar 16: Modus Getar ke-5 Pada Solidwork.

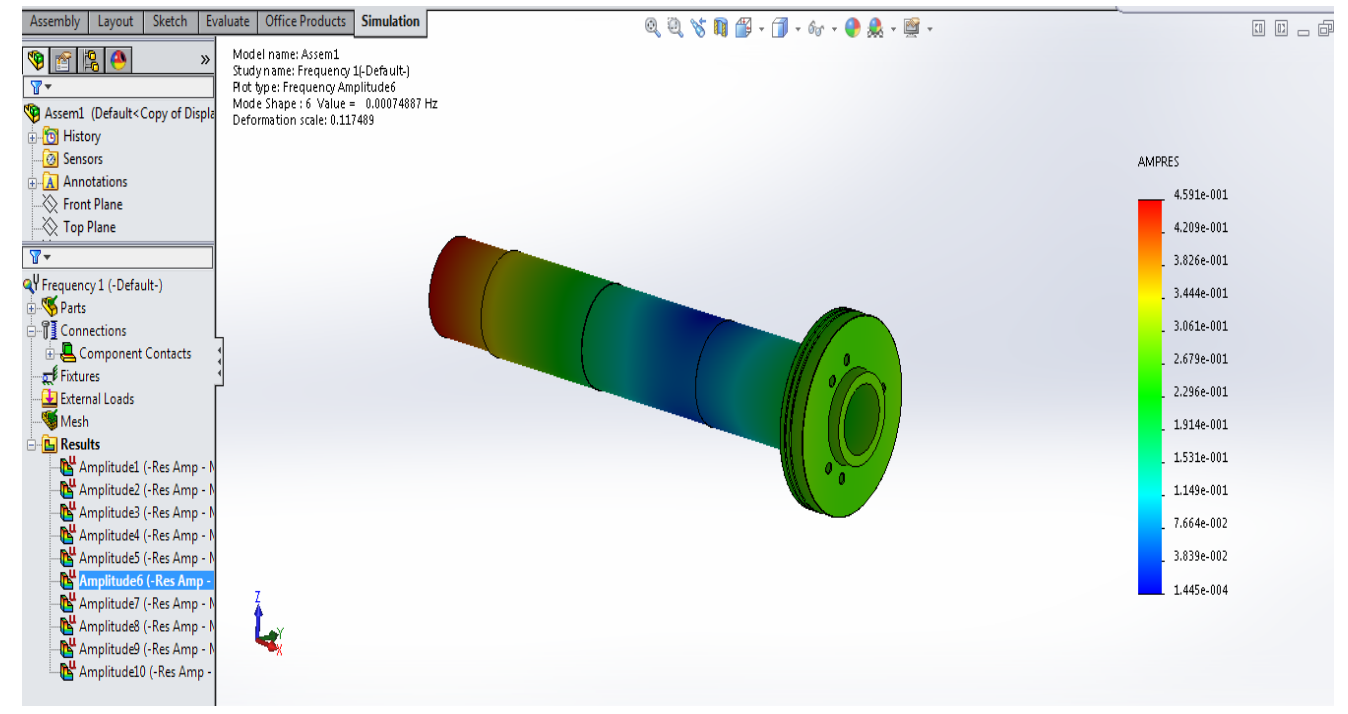

Gambar 17: Modus Getar ke-6 Pada Solidwork. 


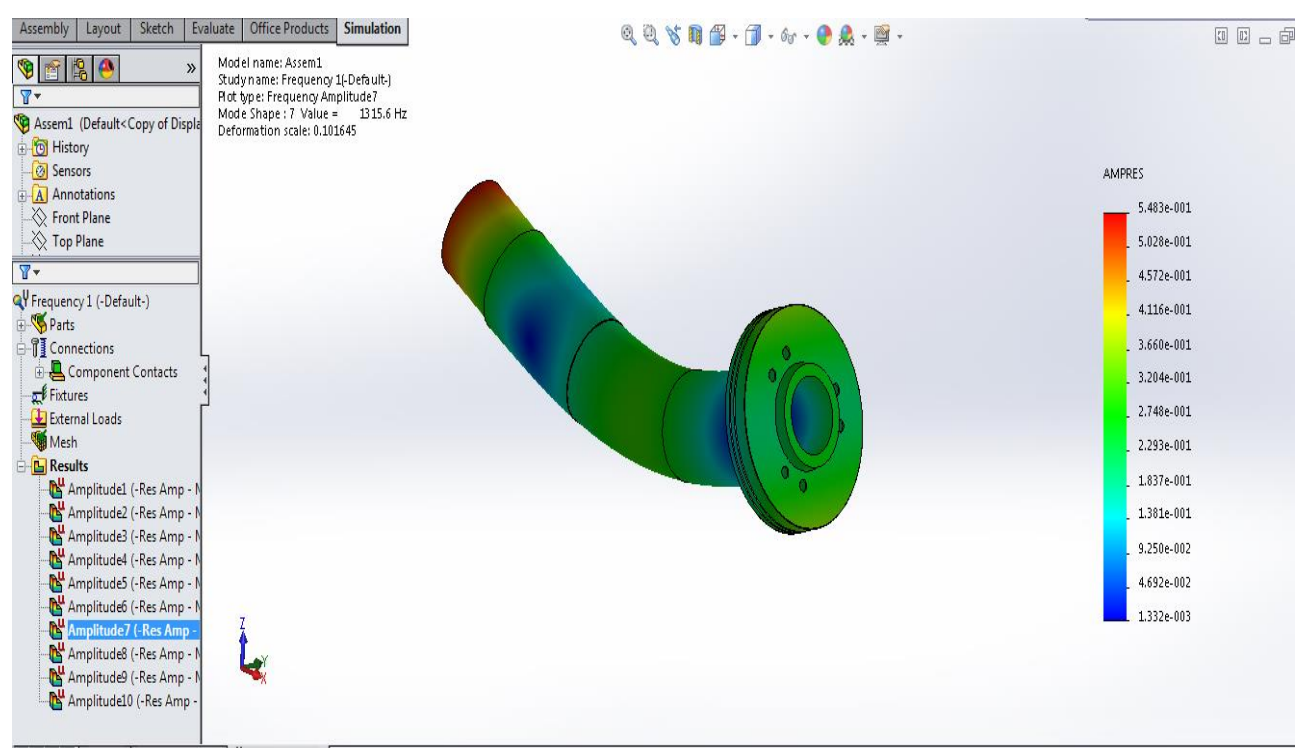

Gambar 18: Modus Getar ke-7 Pada Solidwork.

Tabel 3: Nilai Frekuensi pribadi yang terbaca pada alat ukur modus ke-7 dengan mengatur nilai frekunesi pribadi sebesar $1315.6 \mathrm{~Hz}$.

\begin{tabular}{l|l}
\hline JUMLAH PENGULANGAN PENGUJIAN & NILAI FREKUENSI RATA-RATA (HZ) \\
\hline pengujian 1 & 1318.7 \\
\hline pengujian 2 & 1315 \\
\hline pengujian 3 & 1329.2 \\
\hline pengujian 4 & 1317.2 \\
\hline pengujian 5 & 1322.7 \\
\hline pengujian 6 & 1302.57 \\
\hline pengujian 7 & 1325.56 \\
\hline
\end{tabular}

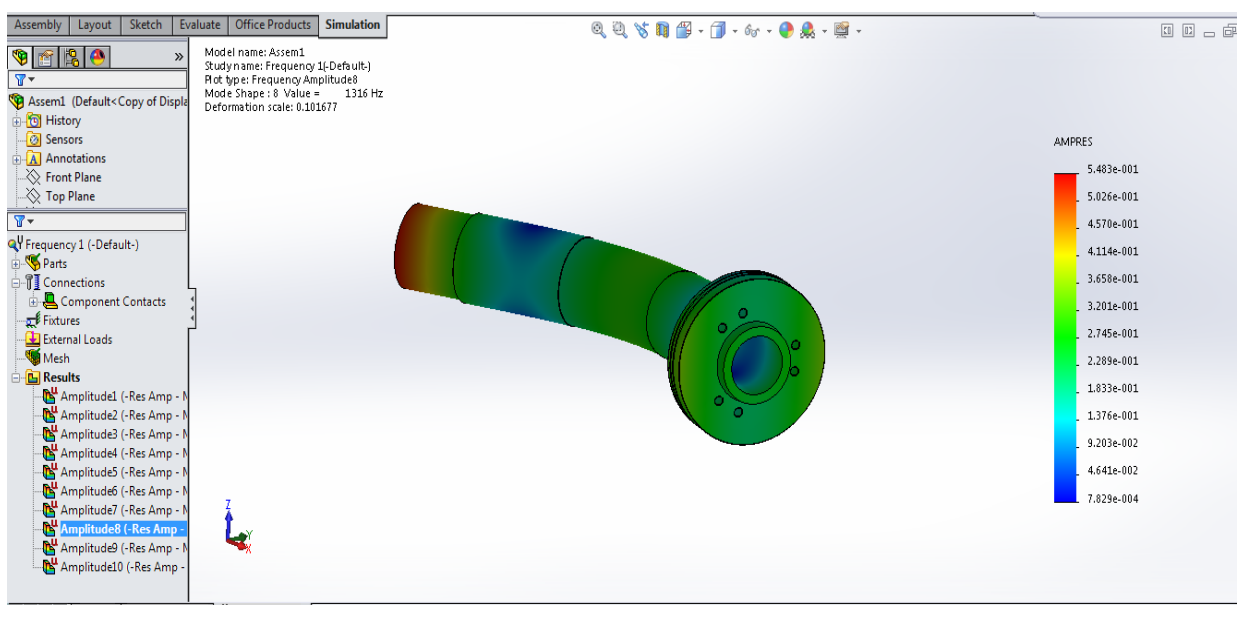

Gambar 19: Modus getar ke-8 Pada Solidwork. 
Tabel 4: Nilai Frekuensi pribadi yang terbaca pada alat ukur modus ke-8 dengan mengatur nilai frekunesi pribadi sebesar $1316 \mathrm{~Hz}$.

\begin{tabular}{l|l}
\hline JUMLAH PENGULANGAN PENGUJIAN & NILAI FREKUENSI RATA-RATA (HZ) \\
\hline pengujian 1 & 1318.7 \\
\hline pengujian 2 & 1315 \\
\hline pengujian 3 & 1329.2 \\
\hline pengujian 4 & 1317.2 \\
\hline pengujian 5 & 1322.7 \\
\hline pengujian 6 & 1302.57 \\
\hline pengujian 7 & 1325.56 \\
\hline
\end{tabular}

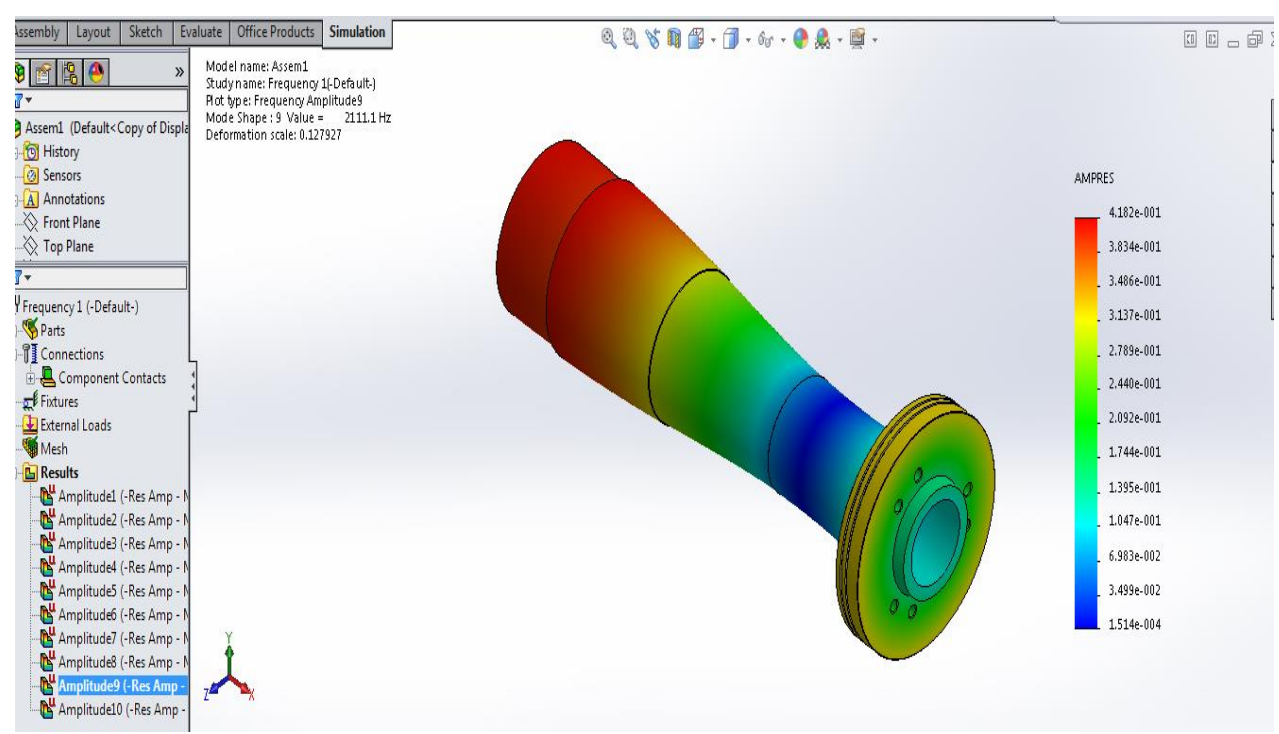

Gambar 20: Modus getar ke-9 Pada Solidwork.

Tabel 5: Nilai Frekuensi pribadi yang terbaca pada alat ukur modus ke-9.

\begin{tabular}{l|l}
\hline JUMLAH PENGULANGAN PENGUJIAN & NILAI FREKUENSI RATA-RATA (HZ) \\
\hline pengujian 1 & 2109.11 \\
\hline pengujian 2 & 2115.5 \\
\hline pengujian 3 & 2114 \\
\hline pengujian 4 & 2124 \\
\hline pengujian 5 & 2128.4 \\
\hline pengujian 6 & 2121.22 \\
\hline pengujian 7 & 2113.5 \\
\hline
\end{tabular}




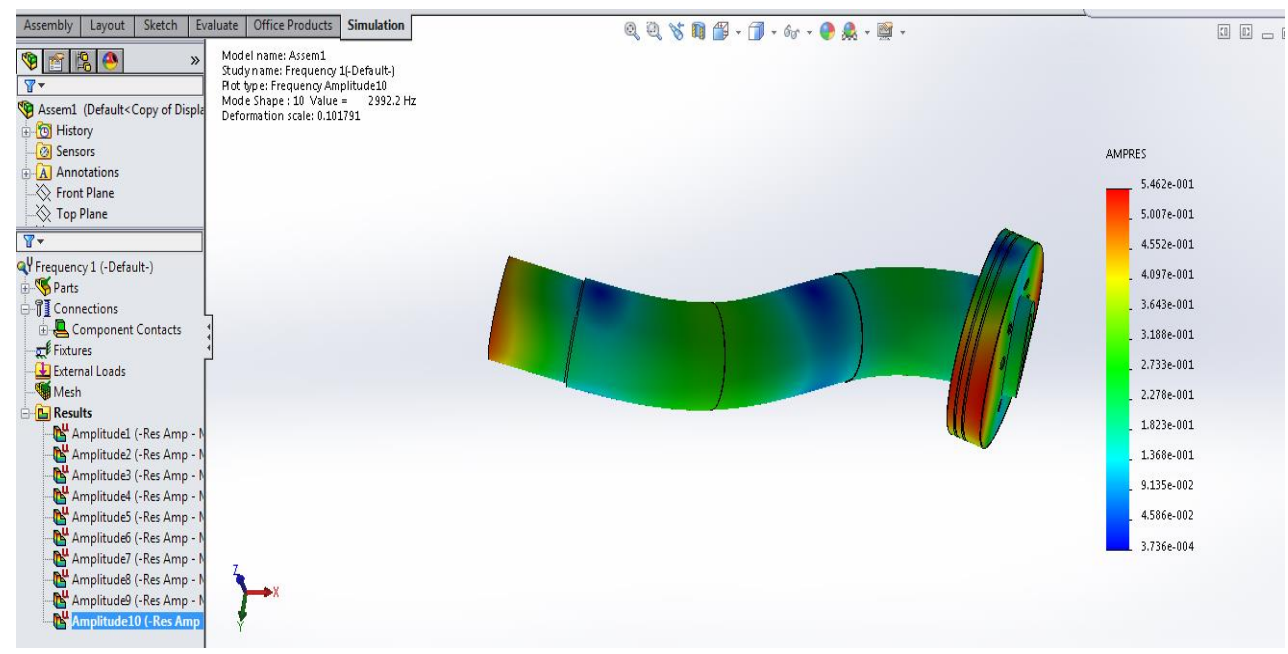

Gambar 21: Modus ke-10 Pada Solidwork

Tabel 6: nilai Frekuensi pribadi yang terbaca pada alat ukur modus ke-10.

\begin{tabular}{l|l}
\hline JUMLAH PENGULANGAN PENGUJIAN & NILAI FREKUENSI RATA-RATA (HZ) \\
\hline pengujian 1 & 2996.9 \\
\hline pengujian 2 & 2987.2 \\
\hline pengujian 3 & 2996.44 \\
\hline pengujian 4 & 2998.2 \\
\hline pengujian 5 & 2997.78 \\
\hline pengujian 6 & 2996 \\
\hline pengujian 7 & 2998 \\
\hline
\end{tabular}

\subsection{Diskusi}

Hasil penelitian yang didapatkan berdasarkan pengukuruan frekuensi pribadi Spindle bubut CNC leadwell T6 menggunakan osiloskop yakogawa DL750P. Hasil pengukuran tersebut dibandingkan dengan simulasi menggunakan software solidwork. Proses simulasi dilakukan terlebih dahulu sebelum dilakukan pengambilan data. Nilai frekuensi pribadi hasil simulasi sebanyak 10 modus getar digunakan untuk pembanding data eksperimen. Setelah dilakukan simulasi, kemudian dilakukan pengujian menggunakan osiloskop yakogawa DL750P. Spindle yang digunakan untuk pengujian dibuat 10 titik pengujian. Setiap titik dilakukan pengambilan data sebanyak 7 kali untuk mendapatkan pengukuran yang akurat. Data hasil pengukuran dihitung selisihnya untuk mengetahui besar error yang didapatkan, selengkapnya dilihat pada tabel 7.

Tabel 7: Besar nilai error dari pengukuran frekuensi pribadi.

\begin{tabular}{l|l|l|l}
\hline $\begin{array}{l}\text { MODE } \\
\text { NO. }\end{array}$ & $\begin{array}{l}\text { FREQUENCY HASIL } \\
\text { SIMULASI (HERTZ) }\end{array}$ & $\begin{array}{l}\text { NILAI FREKUENSI RATA-RATA PADA } \\
\text { ALAT UKUR (HZ) }\end{array}$ & ERROR (\%) \\
\hline 1 & 0 & Tidak terbaca & Tidak terdefinisi \\
\hline 2 & 0 & Tidak terbaca & Tidak terdefinisi \\
\hline 3 & $2.37 \mathrm{E}-09$ & Tidak terbaca & Tidak terdefinisi \\
\hline 4 & 0.00019727 & Tidak terbaca & Tidak terdefinisi \\
\hline 5 & 0.00019771 & Tidak terbaca & Tidak terdefinisi \\
\hline 6 & 0.00074887 & Tidak terbaca & Tidak terdefinisi \\
\hline 8 & 1315.6 & 1318.703855 & 0.235926944 \\
\hline 10 & 1316 & 1318.703855 & 0.205460097 \\
\hline
\end{tabular}


Dari Tabel 7 dapat dilihat bahwa pada pengukuran modus 1 sampai 6 menunjukkan nilai error tidak terdefinisi. Hal ini dikarenakan pengukuran yang dilakukan pada spindle tidak terbaca pada modus tersebut, sedangkan pada hasil simulasi nilai frekuensi pribadi terbaca sangat kecil pada modus 3 sampai 6 . Hasil pengukuran menggunakan alat osiloskop yakogawa DL750P tidak terbaca pada modus 1-6 disebabkan oleh keterbatasan dari kecermatan alatnya. Hasil simulasi dapat terbaca pada modus 3-6 dikarenakan keceramatan pengukuran menggunakan software tidak terbatas. Pada simulasi asalkan ada muncul getaran, maka akan ditampilkan hasilnya walaupun kecil sekali. Hasil perbandingan nilai error frekuensi pribadi yang didapat dari eksperimen pada modus getar ke-7 sebesar 0,23\% lebih besar dibandingkan dengan nilai error pada modus getar ke-8 sebesar 0,20\%. Nilai error modus getar ke-8 lebih besar dibandingkan modus getar ke 10 hanya sebesar $0,11 \%$. Nilai error modus getar ke-9 sebesar $0,32 \%$ yang merupakan nilai error terbesar dibandingkan yang lainnya. Perbedaan hasil simulasi dengan pengukuran langsung kemungkinan disebabkan oleh adanya gangguan yang terjadi saat melakukan pengambilan data secara langsung. Gangguan yang terjadi diantaranya adanya noise dari sekitar area pengambilan data, walaupun itu frekuensinya rendah tapi dapat mempengaruhi hasil penelitian. Data yang didapatkan melalui software tentu tanpa gangguan dari pengaruh luar, sehingga bisa dikatakan hasilnya sudah sesuai.

\section{KESIMPULAN}

Kesimpulan dari penelitian ini adalah sebagai berikut:

1) perbandingan nilai error frekuensi pribadi yang didapat dari eksperimen terhadap simulasi pada modus getar ke-1 sampai dengan modus getar ke-6 tak terdefenisi

2) Nilai error terbesar terdapat pada pengukuran modus getar ke-9 dengan frekuensi pribadi sebesar 2117,9 $\mathrm{Hz}$ yaitu sebesar 0,32\% sedangkan nilai error terkecil pada pengukuran modus getar ke-10 yakni sebesar $0,11 \%$ dengan frekuensi pribadi sebesar $2995,8 \mathrm{~Hz}$

3) Semakin banyak pengujian yang dilakukan maka hasil yang didapat akan semakin akurat.

4) Peletakan sensor yang berbeda, maka akan menyebabkan didapatkannya nilai frekuensi pribadi yang berbeda-beda pula.

5) Perbedaan hasil simulasi dengan pengukuran langsung kemungkinan disebabkan oleh adanya gangguan yang terjadi saat melakukan pengambilan data secara langsung.

\section{PERNYATAAN TERIMAKASIH}

Terima kasih diucapkan kepada semua pihak yang membantu pelaksanaan penelitian ini.

\section{DAFTAR PUSTAKA}

[1] WIBOlO, A., SlAMET,W., SUGIARTO., “Optimasi Parameter Pemotongan Mesin Bubut CNC Terhadap Kekasaran Permukaan Dengan Geometri Pahat Yang Dilengkapi Chip Breaker”, Jurnal Rekayasa Mesin, v. 2, n. 1, pp. 55 - 63, 2011.

[2] YANOTTAMA, M., Pengaruh Arah Pemakanan Trehadap Getaran Mesin Frais universal, Skripsi S1, Jurusan Teknik Mesin, Universitas negeri Semarang, Semarang, Indonesia, 2017.

[3] LIU, S., YANG, B.,"A Closed-form Analytical Solution Method for Vibration Analysis of Elastically Connected Double-beam System", Composite Structures, v. 212, pp. 598-608, March 2019.

[4] LEE, K.J., JEONGN, S., LEE, J.,'Natural frequencies for flexural and torsional vibrations of beams on Pasternak foundation”, Soils and Foundations, v. 54, n. 6, pp. 1202-1211, 2 December 2014.

[5] KAISAN, I. dan RUSIYANTO, "Pengaruh Parameter Pemotongan CNC Milling Dalam Pembuatan Pocket Terhadap Getaran dan Kekasaran Permukaan pada Crankcase Mesin Pemotong Rumput", Jurnal Rekayasa Mesin, v. 11, n.1, pp. 41-49, 2020.

[6] MARIE, B., THOMSEN, J.J., "Experimental Testing of Timoshenko predictions of Supercritical Natural Frequencies and Mode Shapes for Free-free Beams", Journal of Sound and Vibration, Oktober 2019.

[7] PRADIGA, D.A., Studi Eksperimen Analisis Modal untuk Menguji Karakteristik Modus Getar pada Rangka Raket Tenis, Skripsi S1, Jurusan Teknik Mesin, Institut Teknologi Sepuluh Nopember, Surabaya, Indonesia, 2015.

[8] PARAMITA, P.S.S., PUJAYANTO,'Media Pembelajaran Menggunakan Spreadsheet Excel Untuk materi Osilasi Harmonik Teredam”, Dalam: Seminar Nasional Fisika dan Pendidikan Fisika (SNFPF) 2015, pp. 263-269, Surakarta, 2015.

[9] LUO, B., PAN, D., et al.,"A Method to Predict Position-dependent Structural Natural Frequencies of Machine Tool ”, International Journal of Machine Tools and Manufacture, v. 92, pp. 72-84, May 2015. 
[10] SON, L., AFFANDI, A.,“Analisis Frekuensi Pribadi dan Modus getar Struktur Pesawat Tanpa Awak Tipe Flying Wings ”, Jurnal Sistem Mekanik dan Termal (METAL), v. 2, n. 2, pp. 36-42, Oktober 2018.

[11] YANTO, A., HIDAYAT, R., “Analisis Perilaku Dinamik sistem Poros-Rotor 3D”, Jurnal Teknik mesin, v. 4, n. 2, pp. 75-83, Oktober 2014.

[12] CHEN, M.Z.Q., HU, Y.,et al.,"Influence of inerter on natural frequencies of vibration systems", Journal of Sound and Vibration, v. 333, pp. 1874-1887, March 2014.

[13] SHEN, X., ZHANG, Y., and SHEN, T.,"Cylinder pressure resonant frequency cyclic estimation-based knock intensity metric in combustion engines”, Applied Thermal Engineering, v. 158, 113756, pp. 1-12, July 2019.

[14] AYUDDIN dan DESEI, F.L.,"Analisis Kekuatan Struktur Pondasi untuk Dudukan Mesin Turbin", Dalam: Temu Nasional ke- 11 Forum Pendidikan Tinggi Teknik Elektro Indonesia (FORTEI) 2017, pp. 305-308, Gorontalo, 2017.

[15] ROSEMANN, N., FIEDLER, T., et al.,"Determining Young's Modulus of Coatings in Vibration Reed Experiments using Irregularly Shaped Specimens", Result in Materials, v. 2, pp. 1-6, September 2019. 